\title{
Extraordinary runoff from the Greenland ice sheet in 2012 amplified by hypsometry and depleted firn retention
}

\author{
Andreas Bech Mikkelsen ${ }^{1,2}$, Alun Hubbard ${ }^{3,4}$, Mike MacFerrin ${ }^{5}$, Jason Eric Box ${ }^{6}$, Sam H. Doyle ${ }^{4}$, \\ Andrew Fitzpatrick ${ }^{4}$, Bent Hasholt ${ }^{1}$, Hannah L. Bailey ${ }^{7}$, Katrin Lindbäck ${ }^{8}$, and Rickard Pettersson ${ }^{8}$ \\ ${ }^{1}$ Department of Geosciences and Natural Resource Management, University of Copenhagen, Copenhagen, Denmark \\ ${ }^{2}$ Centre for Permafrost (CENPERM), University of Copenhagen, Øster Voldgade 10, Copenhagen, 1350, Denmark \\ ${ }^{3}$ Centre for Arctic Gas Hydrate, Environment and Climate, Department of Geology, University of \\ Troms $\varnothing$, Dramsveien 201, 9037 Norway \\ ${ }^{4}$ Centre for Glaciology, Department of Geography and Earth Sciences, Aberystwyth University, Aberystwyth, \\ SY23 3DB, UK \\ ${ }^{5}$ Cooperative Institute for Research in Environmental Sciences (CIRES), University of Colorado, Boulder, CO, USA \\ ${ }^{6}$ Department of Glaciology and Climate, Geological Survey of Denmark and Greenland, Copenhagen, Denmark \\ ${ }^{7}$ Alfred Wegener Institute, Helmholtz Center for Polar and Marine Research, Periglacial Research Section, \\ 14473 Potsdam, Germany \\ ${ }^{8}$ Department of Earth Sciences, Uppsala Universitet, Villav. 16, 75236 Uppsala, Sweden
}

Correspondence to: Andreas Bech Mikkelsen (bechmikkelsen@gmail.com)

Received: 21 July 2015 - Published in The Cryosphere Discuss.: 3 September 2015

Revised: 18 March 2016 - Accepted: 23 March 2016 - Published: 30 May 2016

\begin{abstract}
It has been argued that the infiltration and retention of meltwater within firn across the percolation zone of the Greenland ice sheet has the potential to buffer up to $\sim 3.6 \mathrm{~mm}$ of global sea-level rise (Harper et al., 2012). Despite evidence confirming active refreezing processes above the equilibrium line, their impact on runoff and proglacial discharge has yet to be assessed. Here, we compare meteorological, melt, firn stratigraphy and discharge data from the extreme 2010 and 2012 summers to determine the relationship between atmospheric forcing and melt runoff at the landterminating Kangerlussuaq sector of the Greenland ice sheet, which drains into the Watson River. The $6.8 \mathrm{~km}^{3}$ bulk discharge in 2012 exceeded that in 2010 by $28 \%$, despite only a $3 \%$ difference in net incoming melt energy between the two years. This large disparity can be explained by a $10 \%$ contribution of runoff originating from above the long-term equilibrium line in 2012 caused by diminished firn retention. The amplified 2012 response was compounded by catchment hypsometry; the disproportionate increase in area contributing to runoff as the melt-level rose high into the accumulation area.
\end{abstract}

Satellite imagery and aerial photographs reveal an extensive supraglacial network extending $140 \mathrm{~km}$ from the ice margin that confirms active meltwater runoff originating well above the equilibrium line. This runoff culminated in three days with record discharge of $3100 \mathrm{~m}^{3} \mathrm{~s}^{-1}\left(0.27 \mathrm{Gt} \mathrm{d}^{-1}\right)$ that peaked on 11 July and washed out the Watson River Bridge. Our findings corroborate melt infiltration processes in the percolation zone, though the resulting patterns of refreezing are complex and can lead to spatially extensive, perched superimposed ice layers within the firn. In 2012, such layers extended to an elevation of at least $1840 \mathrm{~m}$ and provided a semiimpermeable barrier to further meltwater storage, thereby promoting widespread runoff from the accumulation area of the Greenland ice sheet that contributed directly to proglacial discharge and global sea-level rise.

\section{Introduction}

The Greenland ice sheet is losing mass at $0.7 \mathrm{~mm} \mathrm{yr}^{-1}$ equivalent of global sea-level rise, the majority of which is attributed to surface ablation that is set to increase under atmo- 
spheric warming (Enderlin et al., 2014; Hanna et al., 2013). Although surface-meltwater production can be readily calculated by regional climate models (e.g. Fettweis et al., 2011), such estimates do not equate directly to sea-level rise due to the hydrological processes that buffer and store melt on, within and beneath the ice sheet. It has been argued that retention at the ice sheet surface has the greatest capacity to offset future sea-level rise, particularly refreezing across the wet-snow/percolation zone above the equilibrium line (Pfeffer et al., 1991). Within the percolation zone, melt generated at the surface infiltrates and refreezes within the snowpack, increasing its density, forming firn and thereby retaining potential runoff (Pfeffer et al., 1991; Braithwaite et al., 1994). Harper et al. (2012) analysed a series of cores and groundpenetrating radar profiles collected across an $85 \mathrm{~km}$ transect above the equilibrium line at $\sim 69.5^{\circ} \mathrm{N}$ to quantify the waterstorage capacity of the percolation zone. Their analysis revealed repeated infiltration events in which surface melt penetrated to more than $10 \mathrm{~m}$ depth and refroze as superimposed ice layers. Although the resulting patterns of vertical densification were complex, they proposed that over a number of decades such infiltration will fill all of the available pore space and provide a storage sink of between 322 to $1289 \mathrm{Gt}$ of melt - equivalent to buffering $\sim 0.9$ to $\sim 3.6 \mathrm{~mm}$ of global sea-level rise.

Below the equilibrium line in spring, meltwater is initially stored within the snowpack, but once the pore space is saturated, it runs off the previous summer's ice surface (IrvineFynn et al., 2011). This runoff either flows directly into the subglacial environment via supraglacial river networks and moulins or is temporarily stored in supraglacial lakes. Such lakes can individually capture up to $10^{7} \mathrm{~m}^{3}(0.01 \mathrm{Gt})$ of water and are estimated to cover up to $3 \%$ of the western sector of the ice sheet (Box and Ski, 2007; Fitzpatrick et al., 2014). Hence, these lakes have the capacity to buffer large volumes of water on timescales from weeks to months, or potentially years if they do not drain (e.g. Fitzpatrick et al., 2014; Selmes et al., 2011). Once filled, the lakes contribute directly to proglacial discharge either by overflowing into downstream moulins or by rapid in situ drainage into the subglacial environment (e.g. Das et al., 2008; Doyle et al., 2013; Tedesco et al., 2013a). It is observed that supraglacial lakes often drain in clusters that could cause major peaks in proglacial discharge (Doyle et al., 2013; Fitzpatrick et al., 2014). Ice-dammed proglacial lakes also provide a temporary buffer to proglacial discharge that can flood rapidly (Carrivick and Quincey, 2014; Mikkelsen et al., 2013; Russel et al., 2011).

Quantifying these water-storage mechanisms across the ice sheet is important since the consequence of enhanced melt on mass-balance and sea-level contribution depends on the fraction of melt that escapes to the ocean. The area of the ice sheet undergoing melt will expand to higher elevations under predicted atmospheric warming, and this could force runoff from well within the ice sheet interior and con- tribute to enhanced sea-level rise (Hanna et al., 2008; Huybrechts et al., 2011; Smith et al., 2015). Expansion of the melt area with warming is further amplified by the ice sheet hypsometry. As the ice surface flattens toward higher elevations, a linear increase in the melt level results in a disproportionate gain in the net surface area exposed to melt conditions. If, however, a significant fraction of that melt is subsequently intercepted and stored by local percolation and refreezing within the snowpack above the equilibrium line, or otherwise at lower elevations in supra- and proglacial lakes, then discharge and sea-level rise is buffered on a timescale of weeks to decades. Although these storage terms have been estimated for the ice sheet (Box and Ski, 2007; Carrivick and Quincey, 2014; Fitzpatrick et al., 2014; Harper et al., 2012; Humphrey et al., 2012), their combined impact on runoff and proglacial discharge in an integrated study has yet to be quantitatively assessed.

Here, by reference to the two extreme warm summers of 2010 and 2012, we quantify the efficacy of surfacemelt storage processes across the Greenland ice sheet using a hydrological-budget approach. We compare the seasonal production of surface melt with proglacial discharge across a well-defined, land-terminating catchment that drains the Kangerlussuaq (K-transect) sector of the ice sheet. By drawing on satellite imagery, photographs and a series of snow pits and firn cores above the equilibrium line, we relate the calculated residual difference in the hydrological budget through time to the spatial extent and effectiveness of potential meltwater retention across the catchment, with particular attention to the percolation zone.

\section{The exceptional 2010 and 2012 melt seasons}

The record warm Greenland summers of 2010 and 2012 have been documented using regional atmospheric modelling (Tedesco et al., 2013b), microclimatological observations (Bennartz et al., 2013; van As et al., 2012), microwave and optical remote sensing (Nghiem et al., 2012; Smith et al., 2015; Tedesco et al., 2011) and in situ data (McGrath et al., 2013). In both years, a blocking high pressure system, associated with a strongly negative summer North Atlantic oscillation (NAO) anomaly, was present in the mid-troposphere over Greenland (Hanna et al., 2014). The resulting circulation pattern advected warm southerly winds over the western flank of the ice sheet, forming an insulating heat bubble over Greenland (Neff et al., 2014) that promoted enhanced surface heating.

During summer 2010, higher than average near-surface air temperatures in western and south-western regions of the ice sheet led to early and prolonged summer melting and metamorphism of surface snow, significantly reducing surface albedo and thereby enhancing sunlight absorption (van As, 2012; Box et al., 2012; Tedesco et al., 2013b). Similarly, in summer 2012 high near-surface air temperatures and a low-surface albedo enabled high melt rates (Ngheim et al., 


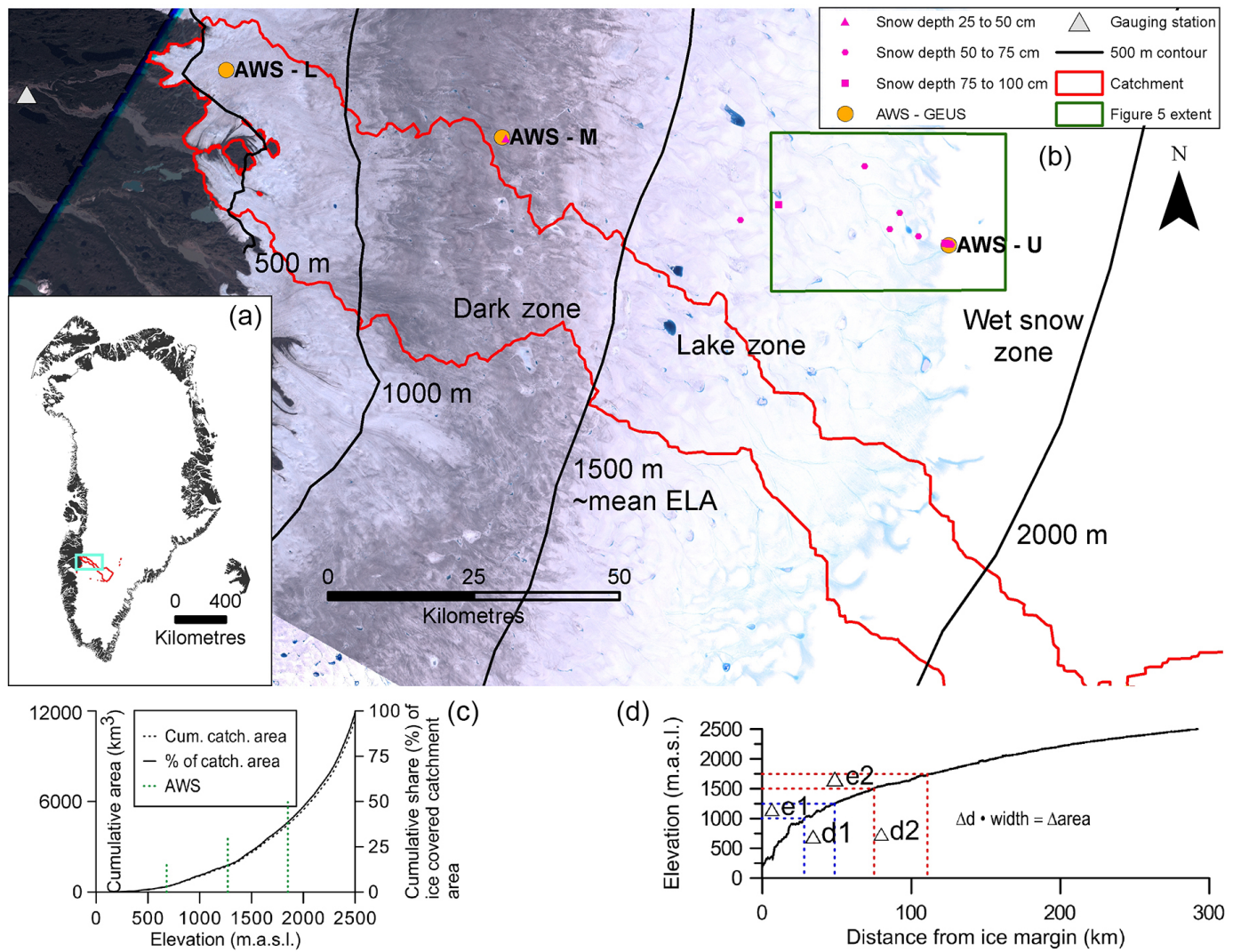

Figure 1. Panel (a) shows the location of the study area (cyan) and catchment (red) in Greenland is shown on the inset map. Panel (b) shows the map of the study area overlain with the location of the AWS, gauging station, catchment area and snow pit sites. The background Landsat 7 image, which was acquired on 16 July 2012, reveals that superglacial lakes and streams formed at an exceptional and unprecedented elevation of $\sim 1800 \mathrm{~m}$ a.s.l. The non-linear increase in the size of the catchment with increasing elevation is shown in (c), and (d) shows an example of the impact on melt area with a rise in the snow line of $250 \mathrm{~m}$ with a $500 \mathrm{~m}$ displacement in different start elevations (hypsometric effect).

2012). During 2012, exceptional melt events were concentrated in two periods in mid-July and late July. On 12 July, a ridge of warm air stagnated over Greenland and melt occurred over $98.6 \%$ of the surface of the ice sheet - even extending to the perennially frozen, high-elevation interior at the ice divide (McGrath et al., 2013; Nghiem et al., 2012). In the Kangerlussuaq sector, the focus of this study, the 11 July 2012 melt event had a severe and direct hazardous impact with the washout and partial destruction of the Watson River Bridge on the 11 July 2012 (https://youtu.be/RauzduvIYog), indicating that proglacial discharge was at its highest stage since the early 1950s when the bridge was constructed. A second phase of exceptional conditions returned in late July 2012 when over $79 \%$ of the ice-sheet surface was again exposed to exceptional melt (Nghiem et al., 2012). Bennartz et al. (2013) found that low-level clouds played an important role by increasing near-surface air temperatures via their effect on radiative absorption: sufficiently low to enhance the downward infrared irradiance whilst optically thin enough to allow solar radiation to penetrate.
These conditions had the capacity to force rapid and extreme ice-sheet melt and runoff that was visible from space and in time-lapse camera sequences of, for example, proglacial flooding (Smith et al., 2015) and turbulent plumes active at the fronts of tidewater glaciers (Chauché et al., 2014; Nick et al., 2012). Nevertheless, the challenge of measuring discharge at marine-terminating glaciers and the lack of proglacial gauging stations in Greenland mean that this inference can only be assessed at a broad, regional scale using satellite-derived estimates of mass balance (e.g. GRACE; Ewert et al., 2012). Hence, the years of exceptionally warm atmospheric forcing in 2010 and 2012 present an ideal natural experiment and opportunity to assess and quantify the catchment-wide efficacy and spatio-temporal footprint of melt, storage and runoff processes across the ice sheet. 


\section{Study area and methods}

\subsection{Study area}

We focus on the $\sim 12500 \mathrm{~km}^{2}$ catchment that drains into the Watson River from the land-terminating Kangerlussuaq sector on the western margin of the ice sheet. The catchment is $95 \%$ glaciated and comprises four main outlet glaciers centred on Russell Glacier (Fig. 1). Within this catchment, the ice surface rises $\sim 90 \mathrm{~km}$ from the ice margin at $550 \mathrm{~m}$ a.s.l. to the mean 1990 to 2010 equilibrium line altitude (ELA) of $1553 \mathrm{~m}$ a.s.l. (van de Wal et al., 2012, 2015), and extends a further $\sim 150 \mathrm{~km}$ across the accumulation area to the ice divide at $\sim 2550 \mathrm{~m}$ a.s.l.

\subsection{Proglacial discharge measurements}

Proglacial river discharge was gauged near the Watson River Bridge in Kangerlussuaq (Fig. 2), located $22 \mathrm{~km}$ from the icesheet margin and with a direct outlet into the Kangerlussuaq Fjord. Due to orographic shielding by Sukkertoppen ice cap the Kangerlussuaq region is exceptionally dry, with a mean annual precipitation of $149 \mathrm{~mm}$ (Box et al., 2004; van den Broeke et al., 2008). Land-surface water losses from evaporation and sublimation further minimise the land-area contribution to runoff compared to the ice-sheet component (Hasholt et al., 2013). The Watson River discharge was determined using the stage-discharge relationship presented in Hasholt et al. (2013). Water stage was recorded by pressure transducers on a stable cross section $\sim 100 \mathrm{~m}$ upstream from the bridge. The discharge $Q$ is given by the following equation:

$Q=V \times A$,

where $V$ represents the mean velocity in the river cross section and $A$ is the cross-sectional area. The surface velocity $(V)$ was measured by means of a float and converted into mean cross-sectional velocity by applying a reduction factor of 0.95 (Hasholt et al., 2013). The cross-sectional area (A) used for discharge calculations is based on the deepest sounding of the channel bottom after the winter ice melts in spring. The combined uncertainty in the cross-sectional area and velocity measurements is estimated to be $15 \%$ (Hasholt et al., 2013). However, here we also conservatively include the possibility of a systematically deeper cross section due to bed erosion within the deepest of the two channels during the runoff season. Therefore we estimate the upper limit in the annual cumulative discharge for 2010 and 2012 at +44 and $+32 \%$ respectively. The instantaneous potential error varies with the discharge rate and is plotted together with the measured discharge (Fig. 3d and e).

During the flood event on 11 July 2012 the water level exceeded the previously observed maximum water stage by $1.65 \mathrm{~m}(15 \%)$ and the stage-discharge relationship was extrapolated accordingly. Our stage-discharge relationship was also altered by the partial removal of a road dam (part of

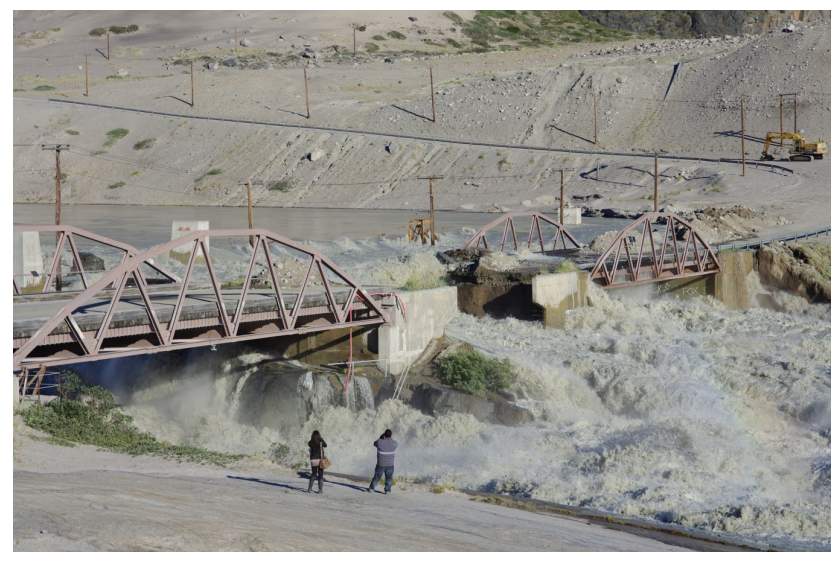

Figure 2. Photograph taken at 18:00 West Greenland Summer Time on 11 July 2012 during the flood with the Watson River Bridge being washed out. Image courtesy of Jens Christiansson.

the bridge construction), which opened up two new, shallow channels in between and south of the two original channels (Fig. 2). We measured the cross-sectional area of the two new channels after the flood had subsided and, by combining these with measurements of stage from timestamped timelapse photographs, we estimate that these new channels were 1.5 and $2.5 \mathrm{~m}$ deep at peak flow.

The surface velocity in these new channels was calculated assuming the conservation of energy in fluids:

$v=\sqrt{2 g h}$,

where $v$ is the surface velocity of the water, $g$ is the gravitational acceleration $\left(9.82 \mathrm{~m} \mathrm{~s}^{-2}\right)$ and $h$ is the water level. Uncertainty in $v$ for the two new channels is mainly attributed to the determination of stage from time-lapse photos, which we conservatively estimate at $\sim 30 \%$. The two original bedrock channels remained intact and we assume that the hydraulic conditions in these channels did not change substantially during the flood event. For the period after the bridge foundation was partially washed out, the discharge in the new channels is added to that calculated based on the stage-discharge relationship for the original channels. We estimate that the formation of the two new channels during the flood event resulted in a small relative (i.e. $<3 \%$ ) contribution to the total discharge.

\subsection{Meteorological measurements}

Automatic weather stations (AWS) are located at three elevations: 732 (AWS_L), 1280 (AWS_M) and $1840 \mathrm{~m}$ a.s.1. (AWS_U; see van As et al., 2012). Each AWS, recorded nearsurface $(2-3 \mathrm{~m})$ air temperature, humidity, wind speed, upward and downward short-wave and long-wave irradiance as well as air pressure. 

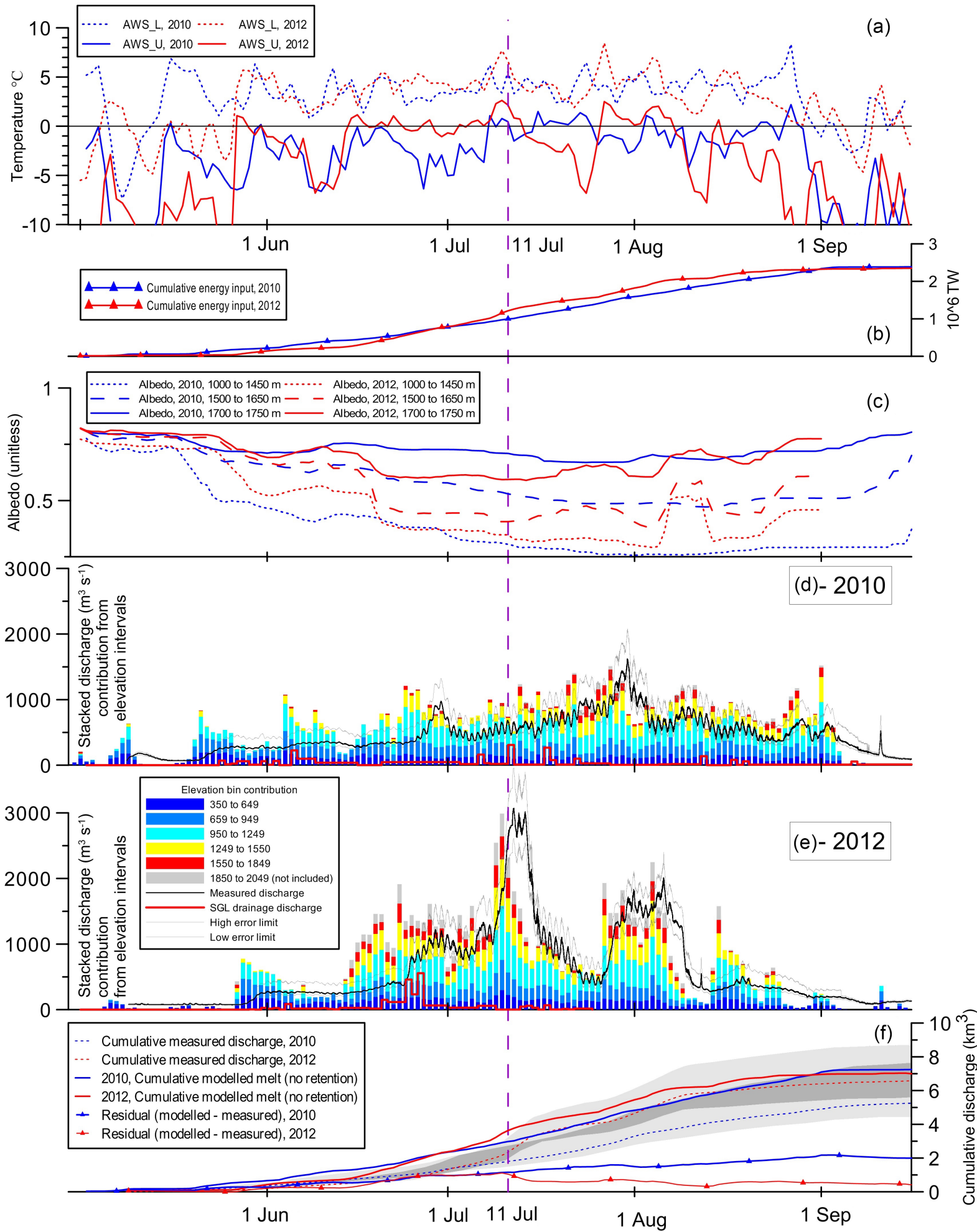

Figure 3. Meteorological records, discharge measurements and modelled melt runoff for the study area during 2010 and 2012 , including (a) daily average air temperature at AWS_L and AWS_U. To avoid cluttering, temperatures below $-10^{\circ} \mathrm{C}$ are not shown. Likewise the air temperatures at AWS_M, which usually lies between that of AWS_L and AWS_U, are not plotted. Panel (b) shows the calculated cumulative energy input, (c) the albedo at three different elevation bands, (d, e) the proglacial discharge, supraglacial lake drainage volume and modelled melt runoff, and (f) the cumulative proglacial discharge, modelled melt runoff and residual between the two. The dashed vertical purple line demarks the bridge washout on 11 July 2012. The uncertainty in discharge estimates is shown using grey lines on (d) and (e) and by grey shading on (f). Where the uncertainty estimates for 2010 and 2012 overlap on (f), a darker shade of grey is used. 


\subsection{Snow and ice albedo}

Surface albedo was determined from the Moderate Resolution Imaging Spectroradiometer (MODIS) by NASA's Terra Satellite, interpolated onto a $5 \mathrm{~km}$ grid from 1 May 2010 to 31 September 2012. An 11-day running median was taken to reject noise caused by contrails and cloud shadows (Box et al., 2012). From these data, an albedo time series was formed for the glaciated part of the Watson River catchment area defined as $67 \pm 0.2^{\circ} \mathrm{N}$ and west of $44^{\circ} \mathrm{W}$. The data were averaged in $100 \mathrm{~m}$ elevation intervals on the basis of Scambos and Haran (2002). The resulting albedo product was divided into three approximately equal area bands corresponding to the physiographic regions dominated by surface-impurity darkness (1000 to $1450 \mathrm{~m}$ a.s.1.), lakes (1500 to $1650 \mathrm{~m}$ a.s.l.) and wet snow (1700 to $1850 \mathrm{~m}$ a.s.l.; Fig. 1; see also Wientjes et al., 2012; Wientjes and Oerlemans, 2010).

\subsection{Surface energy budget model}

The surface energy budget (SEB) was calculated daily across the glacierized catchment following van As et al. (2012). The model calculates radiative, turbulent, rain and subsurface (conductive) energy fluxes using data from the three AWS measurements as input, interpolated into the same $100 \mathrm{~m}$ elevation bins as the albedo data. The MODIS albedo data were used in the calculation of net short-wave radiation. The sensible and latent energy fluxes were calculated from nearsurface gradients of wind speed, temperature and humidity using a stability correction. The surface mass balance (SMB) was calculated as the sum of solid precipitation, surface melt and sublimation. The model was validated against independent K-transect measurements (e.g. van de Wal et al., 2012) and its performance was found to be within $4 \%$ of the observed values. The net energy available for melt across the entire glacierized catchment was determined by integrating the calculated energy flux $\left(\mathrm{W} \mathrm{m}^{-2}\right)$ for each elevation interval by area. For the purpose of quantifying the potential net melt available for runoff, refreezing and retention, parameterisations were disabled.

\subsection{Firn-saturation model}

Based upon firn core stratigraphy and density measurements at AWS_U, a mass conservation model was used to determine when horizontal water flow might occur if meltwater were not permitted to percolate beneath the massive 2010 ice layers. Water generated by melt at the surface, minus evaporation/sublimation, fills the available pore space of the firn beneath and raises the saturated-water table level. In situ measurements and/or reasonable ranges were assigned for model input values, including the density of fresh snow, the average depth and density of the packed snow layer above the firn, the density of refrozen ice and the amount of water attributed to sublimation and evaporation. Ten million $\left(10^{7}\right)$ Monte Carlo model iterations were run over the range of input variables to produce $95 \%$ confidence intervals of the daily water levels and potential firn-saturation dates at AWS_U.

\subsection{Supraglacial lake drainage}

To determine the extent and timing of supraglacial lake drainage events within the Watson River catchment, an automatic lake classification was applied to daily MODIS MOD09 imagery following Fitzpatrick et al. (2014). Fiftytwo cloud-free MODIS images with an initial resolution of $500 \mathrm{~m}$ were sharpened to $250 \mathrm{~m}$ and processed to derive the surface area and volume of supraglacial lakes. The smallest lake classified was $0.0625 \mathrm{~km}^{2}$, which equates to a single $250 \times 250 \mathrm{~m}$ pixel. Lake areas were classified using an empirically determined threshold of the normalised difference water index (NDWI; Huggell et al., 2002). Lake volume was derived using a reflective index approach after Box and Ski (2007) calibrated against lake bathymetry data acquired in 2010 (Doyle et al., 2013) and subsequently validated against in situ depths from an independent supraglacial lake at $67^{\circ} \mathrm{N}, 48^{\circ} \mathrm{W}$, at $\sim 1420$ m.a.s.l. (Fitzpatrick et al., 2014). The error in our lake area and depth is an estimated $\pm 0.2 \mathrm{~km}^{2}$ per lake and $1.5 \mathrm{~m}$ per pixel respectively. Change in stored volume in each lake was converted to mean discharge rates between cloud-free observations (Fig. 3d and e).

\subsection{Catchment delineation}

A well-documented source of uncertainty in calculating runoff stems from the delineation of hydrologically complex watersheds with rapidly evolving supraglacial stream, river and lake networks (e.g. van As et al., 2012; Fitzpatrick et al., 2014; Smith et al., 2015). Furthermore, supraglacial drainage plays a relatively minor part (albeit a readily observable one) of the entire water transport story and the subsequent routing of meltwater into the subglacial hydrological system via moulins and fractures remains unconstrained. Here we adopt a novel watershed delineation approach based on catchment and drainage routing determined from subglacial hydraulic potential analysis presented by Lindbäck et al. (2015). Lindbäck et al. (2015) demonstrate that the subglacial footprint of the Watson River catchment can migrate northward and capture up to $\sim 30 \%$ of the area of the adjacent Isunnguata Sermia catchment, under varying subglacial water-pressure conditions during the melt season. However, the study also reveals that despite significant hydrological piracy between adjacent catchments, the actual contributing area of the Watson River subglacial catchment, along with its surface hypsometry, remains effectively constant. Lindbäck et al. (2015) also demonstrate that across the lower ablation area (500 to $1250 \mathrm{~m}$ a.s.l.) where meltwater production rates are highest, the subglacial footprint is fixed even under transient waterpressure conditions. Hence, we are confident that the catch- 
ment delineation adopted in this study, based on subglacial hydropotential analysis and the associated melt and runoff calculations, are robust and within error of data sets used.

\subsection{Measurements of firn and snowpack density}

To assess firn and snowpack densification, 15 snow pits and three $7.6 \mathrm{~cm}$ diameter ice cores were obtained from eight sites between 1280 and $1840 \mathrm{~m}$ a.s.l. in April 2012. Two cores were drilled $10 \mathrm{~m}$ apart near AWS_U whilst the third core was drilled at a site located $400 \mathrm{~m}$ to the south of AWS_U. Core stratigraphy was analysed at $\sim 1 \mathrm{~cm}$ vertical resolution before cores were cut into $10 \mathrm{~cm}$ sections and weighed to determine the density profile of the snowpack and firn. A transect of 0.5 to $1 \mathrm{~m}$-deep snow pits between AWS_M and AWS_U were examined to investigate spatial variations in firn and snowpack density (Fig. 1).

\section{Results}

Near-surface air temperatures from three AWS reveal insightful differences in the temporal and altitudinal distribution of energy available for melt between 2010 and 2012 . Melt commenced earlier in 2010 with the lowest AWS_L reaching $6{ }^{\circ} \mathrm{C}$ daily average air temperature by mid-May (Fig. 3a). At AWS_L, melt with air temperature $5^{\circ} \mathrm{C}$ above the seasonal average persisted until 15 September. The duration of the 2010 melt season (119 days) was without precedent for the Kangerlussuaq sector of the ice sheet since 1973 (van As et al., 2012). At the uppermost AWS_U, located $\sim 300 \mathrm{~m}$ above the 1991-2009 baseline ELA of $1524 \mathrm{~m}$ (van de Wal et al., 2012), above-freezing temperatures did not prevail until 8 July 2010. Thereafter mean daily temperatures periodically remained above freezing until September, making 2010 exceptional for melt compared to the long-term average.

During the 2012 melt season, air temperatures above the equilibrium line indicate widespread surface melting from mid-June onwards, including two week-long periods with mean daily air temperatures at AWS_U of $3{ }^{\circ} \mathrm{C}$ (Fig. 3a) during high pressure and clear sky conditions. In the five days leading up to the extreme mid-July 2012 melt event, air temperatures at AWS_M and AWS_U were within $1{ }^{\circ} \mathrm{C}$ despite $70 \mathrm{~km}$ horizontal and $500 \mathrm{~m}$ vertical separation. Hence, from mid-June through to July 2012, the environmental lapse rate was exceptionally low, indicating that melting conditions likely prevailed across an extensive, relatively flat accumulation area. By 12 July, surface melting extended across the entire accumulation area up to the ice sheet divide and indeed, the entire ice sheet including Summit Camp and the NEEM drill site where wet-snow conditions halted airborne skiequipped CH130 operations (McGrath et al., 2013; Nghiem et al., 2012). Below $1000 \mathrm{~m}$ a.s.l., the mean 2012 summer air temperatures were in contrast $0.75^{\circ} \mathrm{C}$ lower than in 2010 ,
Table 1. Energy inputs in 2010 and 2012 (TW).

\begin{tabular}{lccc}
\hline $\begin{array}{l}\text { Energy inputs }-0 \\
\text { to } 1850 \text { m a.sl. }\end{array}$ & 2010 & 2012 & $\begin{array}{c}\text { Difference 2012 } \\
\text { to 2010 }\end{array}$ \\
\hline Energy available for melt & $2.43 \times 10^{6}$ & $2.37 \times 10^{6}$ & $-3 \%$ \\
\hline
\end{tabular}

though still higher than the long-term mean. This in part is explained by the delayed 2012 melt onset that commenced in late May (Fig. 3a).

Somewhat surprisingly, the net cumulative energy available for surface melt across the catchment is virtually equivalent by the end of the 2010 and 2012 summers despite quite different prevailing weather conditions (Fig. 3b). The total energy available for melt across the catchment in 2010 and 2012 calculated from the SEB model up to an elevation of $1840 \mathrm{~m}$ a.s.l. was only $3 \%$ less in 2010 compared to 2012 (Table 1; Supplement for yearly energy balances for the three weather station sites for 2010 and 2012).

MODIS albedo time series (Fig. 3c) binned into three elevation bands equating to the extent of the dark, lake and wet-snow zones. Fig. 3 exhibits complex patterns of change through space and time. In 2012, the albedo decline lags behind 2010 (Fig. 3c) due to the early melt season onset in May 2010 promoted by low 2009/2010 winter snow accumulation (van As et al., 2012). By mid-June, albedo across the dark zone for both years declined to 0.4 . For the remainder of the melt season, the 2010 dark zone albedo was $\sim 0.05$ lower than in 2012 (Fig. 3c), consistent with warmer temperatures and enhanced melt at low elevations in summer 2010. Across the lake and wet-snow zones, a similar pattern of albedo decline is observed up until mid-June. From this time onwards, in contrast to the dark zone, it is the 2012 albedo that is consistently as much as 0.2 lower than 2010 , with the exception of a week-long period when the albedo was reset due to snowfall on 5 August 2012.

The seasonal evolution of daily Watson River discharge and catchment-integrated melt varies considerably between 2010 and 2012 (Fig. 3d to f). In 2010 the integrated melt and proglacial discharge increased at a lower rate than in 2012, despite higher cumulative energy input aided by elevated temperatures combined with lower albedo. Mean daily integrated discharge in 2012 peaked at $3100 \mathrm{~m}^{3} \mathrm{~s}^{-1}$ (equivalent to $\sim 0.27 \mathrm{~km}^{3} \mathrm{~d}^{-1}$; Fig. $4 \mathrm{e}$ ) in mid-July, that washed out Watson River Bridge. With lower temperatures during the week commencing 15 July, melt and discharge dropped to below 2010 levels but returned to high values of at least $1500 \mathrm{~m}^{3} \mathrm{~s}^{-1}$ for 11 days from 26 July 2012, coinciding with the second phase of exceptionally warm conditions. By the end of the melt season, the final total annual discharge in 2012 of $6.8 \mathrm{~km}^{3}$ exceeded that of $5.3 \mathrm{~km}^{3}$ in 2010 by $\sim 28 \%$.

Throughout the 2010 melt season there is a steady increase in the difference between calculated integrated melt across the catchment and cumulative measured discharge, which by the end of the season equates to $36 \%\left(\sim 1.9 \mathrm{~km}^{3}\right)$ of residual 


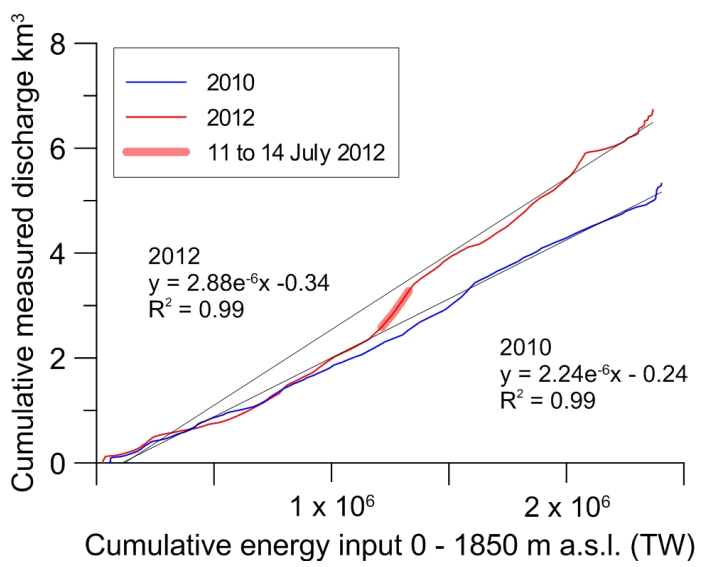

Figure 4. The cumulative measured discharge as a function of the calculated energy input for the catchment up to $1850 \mathrm{~m}$ a.s.l. The flooding period of 11 to 14 July is marked with a bold red line.

melt retained $\left(R^{\prime}\right)$ within the catchment (Fig. 3f). In the period leading up to 11 July 2012, a similar increase in residual $R^{\prime}$ as 2010 indicates substantial meltwater storage within the catchment. However, after 11 July 2012 the residual $R^{\prime}$ drops by $40 \%$ equating to $1 \mathrm{~km}^{2}$ of bulk discharge released within 5 days. Throughout the remainder of the summer, $R^{\prime}$ further diminishes so that only $\sim 0.2 \mathrm{~km}^{3}$ of meltwater is retained by the end of the melt season. This contrasting catchment response to forcing between the two years is demonstrated by plotting cumulative energy input versus cumulative discharge for 2010 and 2012 (Fig. 4). The resulting slope of energy forcing against discharge response is considerably steeper in 2012 than 2010. Hence, for a given energy input, there is a disproportionately larger catchment runoff and discharge response in 2012 compared to 2010, particularly so during the 11 to 14 July 2012 flooding.

The melt totals for each elevation band along with bulk Watson River discharge and their differences are listed in Table 2. Below the long-term ELA of $1550 \mathrm{~m}$, the 2010 and 2012 calculated melt totals are within $7 \%$ of each other. By contrast, in the two elevations bands $1550-1850$ and $1850-2050 \mathrm{~m}$ a.s.l., calculated melt was respectively 75 and $200 \%$ larger in 2012 compared to 2010 (only melt up to $1850 \mathrm{~m}$ a.s.l. is included in Fig. $3 \mathrm{~d}$ and f). Despite this, the absolute difference in total calculated melt between the two years is still only $3 \%$, yet the difference in proglacial discharge between the two years is $28 \%$. Thus, the runoff response to atmospheric forcing is again demonstrated to be more pronounced in 2012, reflected in the larger residual between calculated melt and measured proglacial discharge (Fig. 3f).

Examination of the timing between of catchmentintegrated melt and proglacial discharge (Fig. 3d and e) reveals that meltwater routing through the glacial and proglacial system has a lag of between one and five days during each melt season. In June 2012, the proglacial dis- charge response to melt was dampened and delayed. Prior to the 11 July 2012 extreme melt and discharge, the integrated modelled melt closely resembles the proglacial discharge hydrograph but with a $\sim 3$ day lag. Henceforth, during the remainder of July and the beginning of August 2012, there is a significantly shorter lag between discharge response to melt production. The implication here is that once local meltwater production had been mobilised, even at high elevations above the equilibrium line, the resulting runoff transits through a drainage network up to $160 \mathrm{~km}$ long within three days, thereby contributing to the proglacial discharge peak. Such rapid transit times imply supra- and subglacial flow velocities in excess of $2 \mathrm{~km} \mathrm{~h}^{-1}\left(\sim 0.6 \mathrm{~m} \mathrm{~s}^{-1}\right)$ through an efficient - linked - drainage system. These results are comparable to similar transit velocities derived from tracer experiments conducted up to $57 \mathrm{~km}$ from the ice margin in 2011 (Chandler et al., 2013). The second phase of intense melt, commencing on 26 July 2012 was followed by a rapid rise in proglacial discharge with a lag of just two days. Peak melt during this period occurred on 3 August 2012 with the associated peak in proglacial discharge occurring on the 5 August 2012. The onset of discharge abatement was concurrent with declining air temperatures from 6 August 2012 onwards.

The release of water stored in supraglacial lakes accounts for a minor component of proglacial discharge. In 2012 the majority of lake drainages occurred well before any peaks in proglacial discharge (Fig. 3e and f). The calculated mean drainage rate of $<100 \mathrm{~m}^{3} \mathrm{~s}^{-1}$ for 2012 indicates that the volume of lake drainage water contributed less than $2 \%$ of the total bulk discharge (Fig. 3d and e). The maximum shortterm contribution from lake drainage $\left(0.10 \mathrm{~km}^{3}\right)$ occurred on 23 June 2012 with the synchronous drainage of a local cluster of five lakes (Fig. 3e). Over the following week, approximately $70 \%$ of all water stored in supraglacial lakes across the entire catchment was released (Fig. 3e), which could have accounted for half of the Watson River discharge. However, this multiple lake drainage event occurred $\sim 12$ days before the proglacial discharge peak of 11 July 2012. Supraglacial lakes drain in as little as $2 \mathrm{~h}$ (Das et al., 2008; Doyle et al., 2013) and it is likely that this stored water discharged out of the catchment well before 11 July. One small $\sim 0.02 \mathrm{~km}^{3}$ lake drainage event between 5 and 8 July would have contributed $\sim 2 \%$ to the extraordinary discharge measured between July 10 and $14\left(0.9 \mathrm{~km}^{3}\right)$.

Analysis of MODIS and Landsat imagery indicate that no ice-dammed proglacial lakes within the catchment drained prior to the mid-July flood event, including one that appears to drain regularly in August/September each year. On 11 September 2010 and 12 August 2012, a partially filled proglacial lake did drain (described in Mikkelsen et al., 2013) and even though it is recorded in the Watson River hydrograph, the net contribution to proglacial discharge is minor in 2010 and 2012 (Fig. 3d and e). 


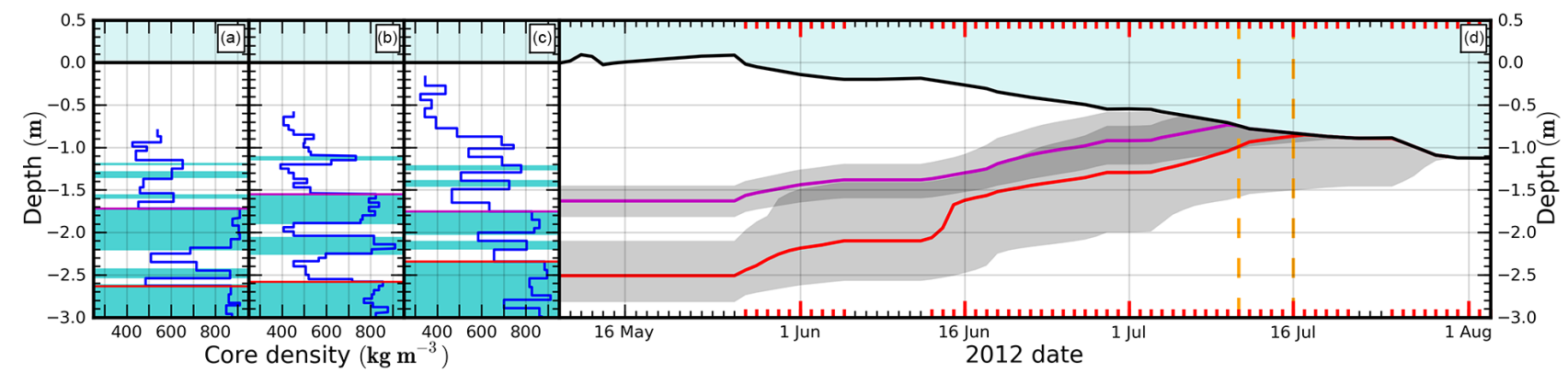

Figure 5. Panels (a-c) show the density profiles of three shallow firn cores drilled at AWS_U in April 2012. The water table is indicated in light blue and ice lenses observed in the core stratigraphy are indicated in cyan. Magenta and red lines indicate two potential sets of "blocking" ice lenses observed in the firn. Panel (d) shows a model simulation of the near-surface water table at AWS_U for each of the two blocking lens assumptions in (a-c), with $95 \%$ confidence intervals in grey. Red ticks on the horizontal axes indicate days above freezing when surface melt would occur. As snow melts above the blocking lenses the water table rises simultaneously until it meets the lowering snow surface. Light blue is free air. The daily snow surface is observed by the adjacent AWS_U AWS. The two dashed orange vertical lines indicate 11 July, the date of the Watson River Bridge destruction and 16 July, when the Landsat image from Fig. 1 shows horizontal water transport in the vicinity of AWS_U.

Table 2. Melt contributions $\left(\mathrm{km}^{3}\right)$ from different elevation intervals integrated through to the end of the melt season, 1 October each year.

\begin{tabular}{lrrr}
\hline & $\begin{array}{r}2010 \\
\mathrm{~km}^{3}\end{array}$ & $\begin{array}{r}2012 \\
\mathrm{~km}^{3}\end{array}$ & $\begin{array}{r}\text { Difference } \\
\%\end{array}$ \\
\hline Below mean ELA & 6.8 & 6.3 & -7 \\
1550 to $1850 \mathrm{~m}$ & 0.4 & 0.7 & 75 \\
1850 to $2050 \mathrm{~m}$ & 0.1 & 0.3 & 200 \\
Total - up to 1850 m & 7.2 & 7.0 & -3 \\
Total - up to 2050 m & 7.3 & 7.3 & 0 \\
\% melt above mean ELA (1550 to 1850 m) & $6(\%)$ & $10(\%)$ & 67 \\
Measured proglacial discharge at Oct. 1 & 5.3 & 6.8 & 28 \\
Integrated melt up 1850 m - measured discharge & 1.9 & 0.2 & -89 \\
Integrated melt up 2050 m - measured discharge & 2.0 & 0.5 & -75 \\
\hline
\end{tabular}

\section{Discussion}

Our analysis reveals that even though the net atmospheric forcing represented by the total incoming energy flux for 2010 and 2012 was similar, the ensuing runoff response was markedly different (Fig. 4). Widespread melt in 2010 has been ascribed to atmospherically sourced heating coupled with a strong albedo feedback promoted by low winter snowfall and early melt onset (Tedesco et al., 2011; Box et al., 2012; van As et al., 2012). Yet low albedo and high air temperatures alone do not explain the $28 \%$ increase in discharge in 2012 compared to 2010. Our analysis also confirms that the release of stored water from supraglacial lakes played a relatively minor role in peak and total proglacial discharge in 2012 (Fig. 3d and e). At most, the supraglacial lake contribution to the 11 July 2012 peak discharge of $3100 \mathrm{~m} \mathrm{~s}^{-1}$ was $\sim 2 \%$. Our results indicate that only a relatively small proportion of the total melt generated at the surface was stored in supra- and proglacial lakes and that the buffering effect of lakes on runoff and discharge is thus limited (Fig. 3d and e). That is not to dismiss the key role of supraglacial lakes in ice sheet hydrology, since it is the critical storage of large volumes of meltwater in them that initiate new hydrofractures and allow them to propagate to the bed - which eventually develop into moulins (Krawczynski et al., 2009; Doyle et al., 2013; Tedesco et al., 2013a). Supraglacial lakes are hence a prerequisite to establishing efficient pathways for injecting surface water into the subglacial environment (Das et al., 2008; Doyle et al., 2013).

We invoke three mutually compatible explanations for the exceptional discharge response observed in 2012: (1) significant melt occurred above the equilibrium line in addition to below it, (2) ice-surface hypsometry amplified the total melt originating from the accumulation zone by disproportionately increasing the contributing area as melt-levels rose and (3) firn retention and storage capacity was reduced within the accumulation zone, thereby promoting widespread runoff. It is significant that such a large runoff contribution from the percolation zone could only have been attained if firn retention capacity was either filled or otherwise severely reduced in 2012 and it is this hypothesis that herein forms the cen- 


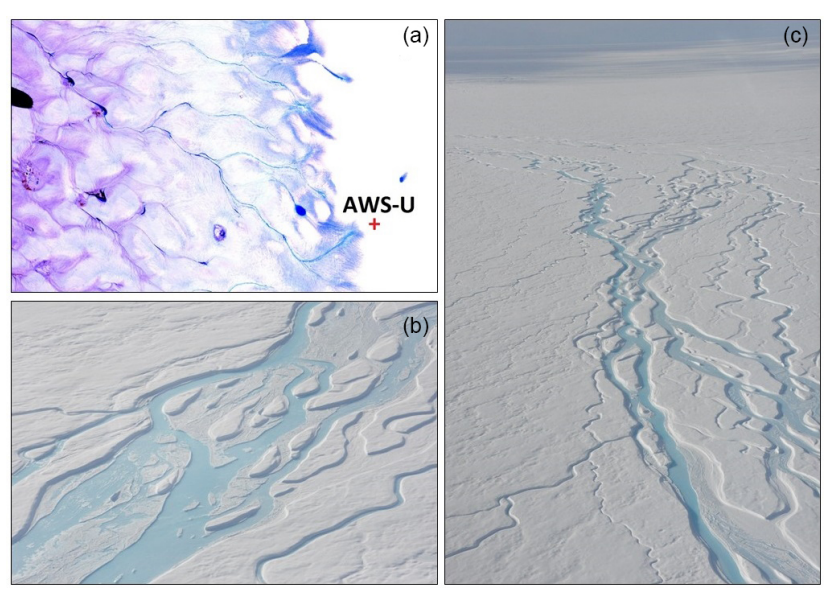

Figure 6. Panel (a) is a zoomed-in Landsat 7 image from 16 July 2012 showing free surface water in the area around AWS_U. The extent is marked on Fig. 1. The scan line correction failure was interpolated using the ENVI "replace bad data" routine based on Band 8 and visible surface water was enhanced using a modified normalized difference water index (Fitzpatrick et al., 2014). (b, c) Oblique aerial photographs of the active supraglacial channel network emerging from AWS_U well within the accumulation zone at $1840 \mathrm{~m}$ a.s.l. and $140 \mathrm{~km}$ from the ice-sheet margin on 13 August 2012. Image courtesy of Paul Smeets.

tral tenet of our discussion. In support of this we present three lines of evidence: (a) snow pit observations and firn core stratigraphy acquired in April 2012 from the percolation zone, (b) observations of surface water networks obtained from satellite imagery and oblique photographs in the vicinity of AWS_U (Fig. 6) and (c) results of our SEB-modelling experiments where total integrated melt is assumed to runoff without any retention or refreezing.

Our core stratigraphic analysis (Fig. 5a to c) reveals significant perched superimposed ice layers that could be capable of blocking surface meltwater infiltration into deeper unsaturated firn layers across the percolation zone. In addition to the shallow firn cores presented (Fig. 5), a persistent and continuous decimetre-thick layer of refrozen, superimposed ice was also observed in 15 snow pits dug along a transect extending from the equilibrium line to AWS_U (Fig. 1). Severely reduced firn retention due to such a superimposed, perched ice lens is further supported by mass conservation modelling of the near-surface water table at AWS_U (Fig. 5d). Here, two potential sets of blocking layers at different levels within the snowpack equate to the thick superimposed ice lenses observed in the firn cores acquired at AWS_U (Fig. 5a to c). For the shallowest of these scenarios, melt and retention calculations predict complete saturation and free surface water available for active runoff by 11 July 2012. These results are consistent with a recent study by Machguth et al. (2016) who also demonstrate reduced meltwater retention across the percolation zone of western sector of the Greenland ice sheet.
Evidence for firn saturation and active surface runoff are furnished independently by the identification of an active supraglacial channel network in Landsat satellite imagery and from oblique photographs taken 13 August 2012 in the vicinity of AWS_U (Fig. 6). Landsat imagery indicates that wet snow, meltwater channels and lakes can be identified up to at least $1750 \mathrm{~m}$ a.s.l. on 23 June 2012 and an active stream network to at least $1800 \mathrm{~m}$ a.s.l. from 5 July 2012 onwards. In early August, 2012 an active channel network was confirmed first-hand during a scheduled maintenance visit to AWS_U (Fig. $6 \mathrm{~b}$ and c). That a well-developed supraglacial hydrological network is clearly observed well above the long-term equilibrium line in the period leading up to the 2012 peak discharge event confirms the assessment of firn retention conditions and the snowpack modelling presented here. Moreover, aerial photos of stream networks to $1840 \mathrm{~m}$ a.s.l. provide clear evidence of widespread runoff from the percolation zone across the western sector of the Greenland ice sheet.

If predicted future atmospheric warming is realised, then the combined impact of reduced firn retention capacity and ice sheet hypsometry will become increasingly apparent through amplification of runoff and discharge response with interior melting. If, as we hypothesise, the extraordinary 2012 discharge was partly derived from runoff originating above the equilibrium line due to an impermeable, superimposed ice lens that formed during previous warm summers, then the 2012 record-warm event itself will lead to the formation of even thicker superimposed ice layers extending yet further into the interior. Hence, we infer a strong positive feedback where a disproportionate and amplified runoff response to future melt events leads to yet more abrupt and severe proglacial discharge, as the 11 July 2012 flood documented here.

In light of these findings, the firn-buffering mechanism proposed for the EGIG line some $120 \mathrm{~km}$ north of our study area and extrapolated across the entire ice sheet by Harper et al. (2012) would appear to be somewhat diminished, at least in the Kangerlussuaq sector. Based on their data and analysis (Fig. 3b and c in Harper et al., 2012) and assuming an equivalent location, our AWS_U site, located $50 \mathrm{~km}$ beyond and $300 \mathrm{~m}$ above the ELA, should have had a buffering capacity equating to a fill-depth of between 2 and $10 \mathrm{~m}$ of meltwater equivalent. In July 2012, up to and including AWS_U at $1840 \mathrm{~m}$ a.s.l. this was not the case and saturated snowpack conditions forced melt to runoff from the percolation zone into a well-developed river network that directly contributed to proglacial discharge and sea-level rise. The next decade will reveal if 2010 and 2012 were exceptions or are part of an emerging new trend. The three years subsequent to the 2012 melt and runoff extreme, i.e. 2013-2015, have been marked by low temperatures, reduced melting and anomalously high accumulation which will have, to some extent, recharged the buffering capacity of the lower accumulation area. Either way, it will be critical to understand the 
future runoff response to variable atmospheric forcing and to determine what portion of the melt generated is intercepted and stored and what fraction contributes directly to proglacial discharge and global sea-level rise.

\section{Conclusions}

Comparison of melt and discharge across the Kangerlussuaq sector in 2010 and 2012 has enabled us to assess and attribute the contrasting runoff response of the Greenland ice sheet to extreme atmospheric forcing. The measured bulk discharge of $6.8 \mathrm{~km}^{3}$ and flooding of the Watson River in 2012 was unprecedented since the Kangerlussuaq Bridge was constructed in the early 1950s, and exceeded the previous record set in 2010 by $\sim 28 \%$. Throughout the 2010 melt season, there was a steady increase in the residual difference between calculated melt across the catchment and cumulative proglacial discharge, which by the end of the season equated to $36 \%\left(\sim 1.9 \mathrm{~km}^{3}\right)$ melt retained within the catchment up to an elevation of $1850 \mathrm{~m}$ a.s.l. In the period up to 11 July 2012, a similar pattern of storage indicates significant catchment retention. However, after 11 July the residual fell by $40 \%$ and diminished further by the end of September, with only $3 \%\left(\sim 0.2 \mathrm{~km}^{3}\right)$ of melt generated within the catchment retained. Surface-melt energy versus proglacial discharge demonstrates an amplified response to forcing in 2012 as compared to 2010, particularly during 11-14 July flood. In 2010 local melting from above the equilibrium line infiltrated and was stored within the firn as superimposed ice layers; hence it did not contribute to proglacial discharge. By contrast, in 2012 our analysis and modelling reveals severely reduced firn-layer infiltration and retention capacity due an extensive perched, thick and semi-impermeable ice lens that formed in previous, anomalously warm melt seasons, including 2010. This resulted in a near-instantaneous runoff and proglacial discharge response from above the accumulation area contributing directly to global sea-level rise.

\section{The Supplement related to this article is available online at doi:10.5194/tc-10-1147-2016-supplement.}

Acknowledgements. We thank Dirk van As and Horst Machguth for assistance in the field and during preparations of the manuscript, including provision of the surface energy balance model, logistics, comments on an initial draft and supervision of Andreas Mikkelsens $\mathrm{PhD}$ project. We also thank Paul Smeets, Institute for Marine and Atmospheric Research, Utrecht University for providing oblique areal photographs taken at AWS_U on 13 August 2011. We acknowledge the Greenland Analogue Project (GAP) - Sub Project A that funded the weather stations and field logistics, the commission on scientific investigations in Greenland, grant no. 07-015998, 09-064628 and 2138-08-0003 and the Danish National Research
Foundation founding Centre for Permafrost (CENPERM), funded by the Danish National Research Foundation, DNRF number 100, Department of Geosciences and Nature Resource Management, University of Copenhagen, Denmark for financial support of the discharge measurements. Jason Eric Box is supported by Denmark's "Det Frie Forskningsråd", Nature and Universe grant DFF 4002-00234. The National Aeronautics and Space Administration (NASA) award NNX10AR76G provided funding for firn table modelling work through the Cooperative Institute for Research in Environmental Sciences, University of Colorado at Boulder, USA. Andrew Fitzpatrick and Sam H. Doyle were supported by NERC and Aberystwyth University doctoral scholarships respectively and fieldwork infrastructure was further funded by NERC Projects NE/G005796/1, NE/G010595/1, NE/H024204/1 and a Royal Geographical Society Gilchrist Fieldwork Award. Alun Hubbard acknowledges salary from the Centre for Arctic Gas Hydrate, Environment and Climate funded through the Research Council of Norway (Grant no. 223259).

Edited by: M. Tedesco

\section{References}

Bennartz, R., Shupe, M. D., Turner, D. D., Walden, V. P., Steffen, K., Cox, C. J., Kulie, M. S., Miller, N. B., and Pettersen, C.: July 2012 Greenland melt extent enhanced by low-level liquid clouds, Nature, 496, 83-86, 2013.

Box, J. E. and Ski, K.: Remote sounding of Greenland supraglacial melt lakes: implications for subglacial hydraulics, J. Glaciol., 53, 257-265, 2007.

Box, J. E., Bromwich, D. H., and Bai, L.-S.: Greenland ice sheet surface mass balance 1991-2000: Application of Polar MM5 mesoscale model and in situ data, J. Geophys. Res., 109, 1-21, doi:10.1029/2003JD004451, 2004.

Box, J. E., Fettweis, X., Stroeve, J. C., Tedesco, M., Hall, D. K., and Steffen, K.: Greenland ice sheet albedo feedback: thermodynamics and atmospheric drivers, The Cryosphere, 6, 821-839, doi:10.5194/tc-6-821-2012, 2012.

Braithwaite, R. J., Laternser, M., and Pfeffer, T.: Variations of nearsurface firn density in the lower accumulation area of the Greenland ice sheet, Pakitsoq, West Greenland, J. Glaciol., 40, 477485, 1994.

Carrivick, J. L. and Quincey, D. J.: Progressive increase in number and volume of ice-marginal lakes on the western margin of the Greenland Ice Sheet, Global Planet. Change, 116, 156-163, 2014.

Chandler, D. M., Wadham, J. L., Lis, G. P., Cowton, T., Sole, A., Bartholomew, I., Telling, J., Nienow, P., Bagshaw, E. B., Mair, D., Vinen, S., and Hubbard, A.: Evolution of the subglacial drainage system beneath the Greenland Ice Sheet revealed by tracers, Nat. Geosci., 6, 195-198, 2013.

Chauché, N., Hubbard, A., Gascard, J.-C., Box, J. E., Bates, R., Koppes, M., Sole, A., Christoffersen, P., and Patton, H.: Iceocean interaction and calving front morphology at two west Greenland tidewater outlet glaciers, The Cryosphere, 8, 14571468, doi:10.5194/tc-8-1457-2014, 2014.

Das, S. B., Joughin, I., Behn, M. D., Howat, I. M., King, M. A., Lizarralde, D., and Bhatia, M. P.: Fracture propagation to 
the base of the Greenland Ice Sheet during supraglacial lake drainage, Science, 320, 778-781, 2008.

Doyle, S. H., Hubbard, A. L., Dow, C. F., Jones, G. A., Fitzpatrick, A., Gusmeroli, A., Kulessa, B., Lindback, K., Pettersson, R., and Box, J. E.: Ice tectonic deformation during the rapid in situ drainage of a supraglacial lake on the Greenland Ice Sheet, The Cryosphere, 7, 129-140, doi:10.5194/tc-7-129-2013, 2013.

Enderlin, E. M., Howat, I. M., Jeong, S., Noh, M. J., van Angelen, J. H., and van den Broeke, M. R.: An improved mass budget for the Greenland ice sheet, Geophys. Res. Lett., 41, 866-872, 2014.

Ewert, H., Groh, A., and Dietrich, R.: Volume and mass changes of the Greenland ice sheet inferred from ICESat and GRACE, J. Geodyn., 59-60, 111-123, 2012.

Fettweis, X., Belleflamme, A., Erpicum, M., Franco, B., and Nicolay, S.: Estimation of the sea level rise by 2100 resulting from changes in the surface mass balance of the Greenland Ice Sheet, in: Climate Change, Geophysical Foundations and Ecological Effects, edited by: Blanco, J. and Kheradmand, H., Croatia, InTech, 2011.

Fitzpatrick, A. A. W., Hubbard, A. L., Box, J. E., Quincey, D. J., van As, D., Mikkelsen, A. P. B., Doyle, S. H., Dow, C. F., Hasholt, B., and Jones, G. A.: A decade (2002-2012) of supraglacial lake volume estimates across Russell Glacier, West Greenland, The Cryosphere, 8, 107-121, doi:10.5194/tc-8-107-2014, 2014.

Hanna, E., Huybrechts, P., Steffen, K., Cappelen, J., Huff, R., Shuman, C., Irvine-Fynn, T., Wise, S., and Griffiths, M.: Increased Run-off from Melt from the Greenland Ice Sheet: A Response to Global Warming, J. Climate, 21, 331-341, 2008.

Hanna, E., Navarro, F. J., Pattyn, F., Domingues, C. M., Fettweis, X., Ivins, E. R., Nicholls, R. J., Ritz, C., Smith, B., and Tulaczyk, S.: Ice-sheet mass balance and climate change, Nature, 498, 5159, 2013.

Hanna, E., Fettweis, X., Mernild, S. H., Cappelen, J., Ribergaard, M. H., Shuman, C. A., Steffen, K., Wood, L., and Mote, T. L.: Atmospheric and oceanic climate forcing of the exceptional Greenland ice sheet surface melt in summer 2012, Int. J. Climatol., 34, 1022-1037, 2014.

Harper, J., Humphrey, N., Pfeffer, W. T., Brown, J., and Fettweis, X.: Greenland ice-sheet contribution to sea-level rise buffered by meltwater storage in firn, Nature, 491, 240-243, 2012.

Hasholt, B., Mikkelsen, A. B., Nielsen, M. H., and Larsen, M. A. D.: Observations of Run-off and Sediment and Dissolved Loads from the Greenland Ice Sheet at Kangerlussuaq, West Greenland, 2007 to 2010, Z. Geomorphol., 57, 3-27, 2013.

Huggell, C., Kaab, A., Haeberli, W., Teysseire, P., and Paul, F.: Remote sensing based assessment of hazards from glacier lake outbursts: a case study in the Swiss Alps, Can. Geotech. J., 39, 316330, 2002

Humphrey, N. F., Harper, J. T., and Pfeffer, W. T.: Thermal tracking of meltwater retention in Greenland's accumulation area, J. Geophys. Res.-Earth, 117, F01010, doi:10.1029/2011JF002083, 2012.

Huybrechts, P., Goelzer, H., Janssens, I., Driesschaert, E., Fichefet, T., Goosse, H., and Loutre, M. F.: Response of the Greenland and Antarctic Ice Sheets to Multi-Millennial Greenhouse Warming in the Earth System Model of Intermediate Complexity LOVECLIM, Surv. Geophys., 32, 397-416, 2011.
Irvine-Fynn, T. D. L., Hodson, A. J., Moorman, B. J., Vatne, G., and Hubbard, A.: Polythermal glacier hydrology: a review, Rev. Geophys., 49, doi:10.1029/2010RG000350, RG4002, 2011.

Krawczynski, M., Behn, M., Das, S., and Joughin, I.: Constraints on the lake volume required for hydro-fracture through ice sheets, Geophys. Res. Lett., 36, 1-5, doi:10.1029/2008GL036765, 2009.

Lindbäck, K., Pettersson, R., Hubbard, A., Doyle, S., van As, D., Mikkelsen, A., and Fitzpatrick, A.: Subglacial water drainage, storage, and piracy beneath the Greenland ice sheet, Geophys. Res. Lett., 42, 7606-7614, 2015.

Machguth, H., MacFerrin, M., van As, D., Box, J., E., Charalampidis, C., Colgan, W., Fausto, R., S., Meijer, H., A., J., MosleyThompson, E., and van de Wal, R., S.: W. Greenland meltwater storage in firn limited by near-surface ice formation, Nature Climate Change, 1-6, doi:10.1038/NCLIMATE2899, 2016.

McGrath, D., Colgan, W., Bayou, N., Atsuhiro, M., and Konrad, S.: Recent warming at Summit, Greenland: Global contect and implications, Geophys. Res. Lett., 40, 2091-2096, 2013.

Mikkelsen, A. B., Hasholt, B., Knudsen, N. T., and Nielsen, K.: Jökulhlaups and sediment transport in Watson River, Kangerlussuaq, West Greenland, Hydrol. Res., 44, 58-67, 2013.

Neff, W., Compo, G. P., Ralph, F. M., and Shupe, M. D.: Continental heat anomalies and the extreme melting of the Greenland ice surface in 2012 and 1889, J. Geophys. Res.-Atmos., 119, 6520 6536, 2014.

Nghiem, S. V., Hall, D. K., Mote, T. L., Tedesco, M., Albert, M. R., Keegan, K., Shuman, C. A., DiGirolamo, N. E., and Neumann, G.: The extreme melt across the Greenland ice sheet in 2012, Geophys. Res. Lett., 39, F01010, doi:10.1029/2011JF002083, 2012.

Nick, F. M., Luckman, A., Vieli, A., van der Veen, C. J., van As, D., van de Wal, R. S. W., Pattyn, F., Hubbard, A. L., and Floricioiu, D.: The response of Petermann Glacier, Greenland, to large calving events, and its future stability in the context of atmospheric and oceanic warming, J. Glaciol., 58, 229-239, 2012.

Pfeffer, W. T., Meier, M. F., and Illangasekare, T. H.: Retention of Greenland Run-off by Refreezing - Implications for Projected Future Sea-Level Change, J. Geophys.Res.-Oceans, 96, 22117 22124, 1991.

Russell, A. J., Carrivick, J. L., Ingeman-Nielsen, T., Yde, J. C., and Williams, M.: A new cycle of jokulhlaups at Russell Glacier, Kangerlussuaq, West Greenland. J. Glaciol., 57, 238-246, 2011.

Scambos, T. A. and Haran, T.: An image-enhanced DEM of the Greenland ice sheet, Ann. Glaciol., 34, 291-298, 2002.

Selmes, N., Murray, T., and James, T. D.: Fast draining lakes on the Greenland Ice Sheet, Geophys. Res. Lett., 38, L15501, doi:10.1029/2011GL047872, 2011.

Smith, L. C., Chu, V. W., Yang, K., Gleason, C. J., Pitcher, L. H., Rennermalm, A. K., Legleiter, C. J., Behar, A. E., Overstreet, B. T., Moustafa, S. E., Tedesco, M., Forster, R. R., LeWinter, A. L., Finnegan, D. C., Sheng, Y., and Balog, J.: Efficient meltwater drainage through supraglacial streams and rivers on the southwest Greenland ice sheet, P. Natl. Acad. Sci. USA, 112, 10011006, 2015.

Tedesco, M., Fettweis, X., van den Broeke, M. R., van de Wal, R. S. W., Smeets, C. J. P. P., van de Berg, W. J., Serreze, M. C., and Box, J. E.: The role of albedo and accumulation in the 2010 melting record in Greenland, Environ. Res. Lett., 6, 1-6, 2011. 
Tedesco, M., Willis, I., Hoffman, M., Banwell, A., Alexander, P., and Arnold, N.: Ice dynamic response to two modes of surface lake drainage on the Greenland ice sheet, Environ. Res. Lett., 8, L034007, doi:10.1088/1748-9326/8/3/034007, 2013a.

Tedesco, M., Fettweis, X., Mote, T., Wahr, J., Alexander, P., Box, J. E., and Wouters, B.: Evidence and analysis of 2012 Greenland records from spaceborne observations, a regional climate model and reanalysis data, The Cryosphere, 7, 615-630, doi:10.5194/tc7-615-2013, 2013b.

van As, D., Hubbard, A. L., Hasholt, B., Mikkelsen, A. B., van den Broeke, M. R., and Fausto, R. S.: Large surface meltwater discharge from the Kangerlussuaq sector of the Greenland ice sheet during the record-warm year 2010 explained by detailed energy balance observations, The Cryosphere, 6, 199-209, doi:10.5194/tc-6-199-2012, 2012.

van de Wal, R. S. W., Greurell, W., van den Broeke, M. R., Reijmer, C. H., and Oerlemans, J.: Surface mass-balance observations and automatic weather station data along a transect near Kangerlussuaq, West Greenland, Ann. Glaciol., 42, 311-316, 2005.

van de Wal, R. S. W., Boot, W., Smeets, C. J. P. P., Snellen, H., van den Broeke, M. R., and Oerlemans, J.: Twenty-one years of mass balance observations along the K-transect, West Greenland, Earth Syst. Sci. Data, 4, 31-35, doi:10.5194/essd-4-312012, 2012. van de Wal, R. S. W., Smeets, C. J. P. P., Boot, W., Stoffelen, M., van Kampen, R., Doyle, S. H., Wilhelms, F., van den Broeke, M. R., Reijmer, C. H., Oerlemans, J., and Hubbard, A.: Self-regulation of ice flow varies across the ablation area in south-west Greenland, The Cryosphere, 9, 603-611, doi:10.5194/tc-9-603-2015, 2015.

van den Broeke, M., Smeets, P., Ettema, J., and Munneke, P. K.: Surface radiation balance in the ablation zone of the west Greenland ice sheet, J. Geophys. Res., 113, D13105, doi:10.1029/2007JD009283, 2008.

Wientjes, I. G. M. and Oerlemans, J.: An explanation for the dark region in the western melt zone of the Greenland ice sheet, The Cryosphere, 4, 261-268, doi:10.5194/tc-4-261-2010, 2010.

Wientjes, I. G. M., De Van Wal, R. S. W., Schwikowski, M., Zapf, A., Fahrni, S., and Wacker, L.: Carbonaceous particles reveal that Late Holocene dust causes the dark region in the western ablation zone of the Greenland ice sheet, J. Glaciol., 58, 787-794, 2012. 